\title{
Grazing intensity effects on litter decomposition and soil nitrogen mineralization
}

\author{
AHMED R. SHARIFF, MARIO E. BIONDINI, AND CAROLYN E. GRYGIEL
}

\begin{abstract}
Authors are former Graduate Research Assistant, Associate Professor, and Research Scientist, respectively, Department of Animal and Range Sciences, North Dakota State University, Fargo, ND 58105.
\end{abstract}

\begin{abstract}
A 2 year study in south central North Dakota determined the responses of (1) litter and root decomposition and nitrogen $(N)$ release, and (2) soil $\mathbf{N}$ mineralization to grazing intensity. The treatments were: long term not grazed, moderate grazing, and heavy grazing. The moderate grazing and the heavy grazing treatments removed $45 \%$ and $77 \%$ of annual above-ground growth respectively. The moderate grazing treatment resulted in higher decomposition and soil $\mathbf{N}$ mineralization rates, and lower $\mathbf{N}$ releases via decomposition than the long term not grazed and heavy grazing treatments. No consistent differences were found between the long term not grazed and heavy grazing treatments. Annual litter and root decomposition rates in the moderate grazing treatment averaged $55 \%$ for $1989-1990$ and $63 \%$ for 1990 1991 while the long term not grazed and heavy grazing treatments had rates for the same periods of $13 \%$ and $19 \%$. The moderate grazing treatment had a net soil $\mathbf{N}$ mineralization of 60 $\mu \mathrm{g} \cdot \mathrm{g}^{-1}$ and $269 \mu \mathrm{g} \cdot \mathrm{g}^{-1}$ during the 1989 and 1990 growing seasons, whereas the long term not grazed and heavy grazing treatments had net soil immobilization for the same periods of $-59 \mu \mathrm{g} \cdot \mathrm{g}^{-1}$ and $-115 \mu \mathrm{g} \cdot \mathrm{g}^{-1}$. Annual $\mathrm{N}$ release from litter and root decomposition in the heavy grazing and long term not grazed treatments averaged $70 \%$ and $38 \%$ respectively during the $1989-1990$ incubation period, and $51 \%$ and $23 \%$ during 1990-1991. The equivalent values for the moderate grazing treatment were $47 \%$ and $-6 \%$ (net $N$ immobilization) for $1989-1990$ and $41 \%$ and $23 \%$ for 1990 1991. Results from this study seem to indicate that the standard grazing rule of "take half leave half" may have a significant impact in $\mathbf{N}$ conservation and the supply of mineral $\mathbf{N}$ for plant growth.
\end{abstract}

Key Words: decomposition, soil N mineralization, soil N immobilization, grazing

Herbivores are an integral component of grasslands and their effect

Support for this study was provided by the Department of Animal and Kange Sciences, the North Dakota Agriculture Experiment Station, and USDA-NRI grant 93 00501. Our sincere appreciation is extended to Paul and Anne Nyren and Bob Parton of the Central Grasslands Research Center, Streeter, North Dakota, for providing field research facilities and to Dr. William Barker, Dr. Donald Kirby, and Dennis Whitted of Animal and Range Sciences Department for their diverse contributions. This is a North Dakota Agriculture Experiment Station Publication Number 2195

Manuscript accepted 27 May 1994. at the ecosystem level may include nutrient transformation and translocation, nutrient flow rates, and nutrient availability, due to feedbacks between plant responses to grazing and nitrogen $(\mathrm{N})$ cycling (Briske and Heitschmidt 1991. Holland et al. 1992). Grazing can influence soil $\mathrm{N}$ mineralization-immobilization (McNaughton et al. 1988), facilitate rapid substrate decomposition (Singh et al. 1991), as well as increase the rate of $\mathrm{N}$ recycling as a result of dung and urine depositions (Bauer et al. 1987). Grazing may also increase nutrient availability by maintaining a pool of readily mineralizable organic nutrients near the soil surface where it is more accessible to plants and microbes (Archer and Smeins 1991).

One limitation of the available empirical data that relates aboveand belowground decomposition and soil $\mathrm{N}$ dynamics to grazing intensity is that most information has been derived primarily from grazed systems where herbivore density and movement were not regulated. In these systems, primary production and herbivore density fluctuate widely in a series of continuous feedback loops related to climatic variation (Sinclair 1975, Walker et al. 1987). In addition to the intrinsic limitations of the available data, a paucity of empirical data exists in the Northern Great Plains with regard to the impact of grazing intensity on litter decomposition and soil $\mathrm{N}$ dynamics. This study was designed to address the effect that grazing intensity has on: (1) litter and root decomposition and $\mathrm{N}$ release; and (2) soil $\mathrm{N}$ mineralization and immobilization.

\section{Methods}

\section{Study Site}

The study was conducted at the Central Grasslands Research Center (CGRC) near the eastern edge of the Missouri Coteau, 10.5 $\mathrm{km}$ northwest of Streeter, North Dakota. The study site is typical of rangelands in the Missouri Coteau, which consist of a mosaic of soil types and range sites. Silty range sites (well drained soils that are moderately fine in texture) dominate the study site. The common soil taxonomic unit of the silty range sites is the Williams Series (fineloamy, mixed Typic Argiboroll) (USDA Soil Conservation Service 1984). The mean annual precipitation for the study area is $432 \mathrm{~mm}$, of which $70 \%$ is received in the growing season (May-September). The total annual precipitation for 1989 and 1990 were $455 \mathrm{~mm}$ and $415 \mathrm{~mm}$, respectively. The average annual snowfall is $864 \mathrm{~mm}$. The January mean temperature is $-14^{\circ} \mathrm{C}$ while frost penetration ranges from $1.4 \mathrm{~m}$ to $2 \mathrm{~m}$. Summer temperatures are highest in July with a mean of $21^{\circ} \mathrm{C}$, and the mean freeze-free period is approximately 120 days (Jensen 1972).

The most extensive graminoid-dominated community on the silty range site is the Bouteloua gracilis-Stipa comata-Carex heliophila 
complex (Lura et al. 1988). The dominant species are sun sedge (Carex heliophila Mack.), needle-and-thread (Stipa comata Trin. and Rupr.), western wheatgrass (Agropyron smithii Rydb.), and blue grama (Bouteloua gracilis [H.B.K.] Lag. ex Stud.). Forbs and shrubs comprise about $10 \%$ of the total cover and include yellow sweet clover (Melilotus officinalis [(L.) Pall.]), prairie trefoil (Lotus purshianus Clem. and Clem.), western rock jasmine (Androsace occidentalis Pursh.), common buckthorn (Rhamnus cathartica L.), and scarlet globemallow (Sphaeralcea coccinea [(Pursh) Rydb.]).

\section{Experimental Design}

The experiment was located in a section of land that had not been subjected to livestock grazing since 1979 (Lura et al. 1988). The experiment was organized as a completely randomized design with 3 treatments: ungrazed control, moderate grazing, and heavy grazing. Each treatment was replicated 3 times for a total of 9 pastures of 13.2 ha each. The moderate grazing and the heavy grazing treatments were grazed from mid-May through September with the goal of removing $50 \%$ or $100 \%$ of the annual above-ground growth. The actual levels achieved during the study were $45 \%$ and $77 \%$ for the moderate grazing and heavy grazing treatments, respectively (Shariff 1993). The site was grazed by yearling steers in 1989 and by bred heifers in 1990
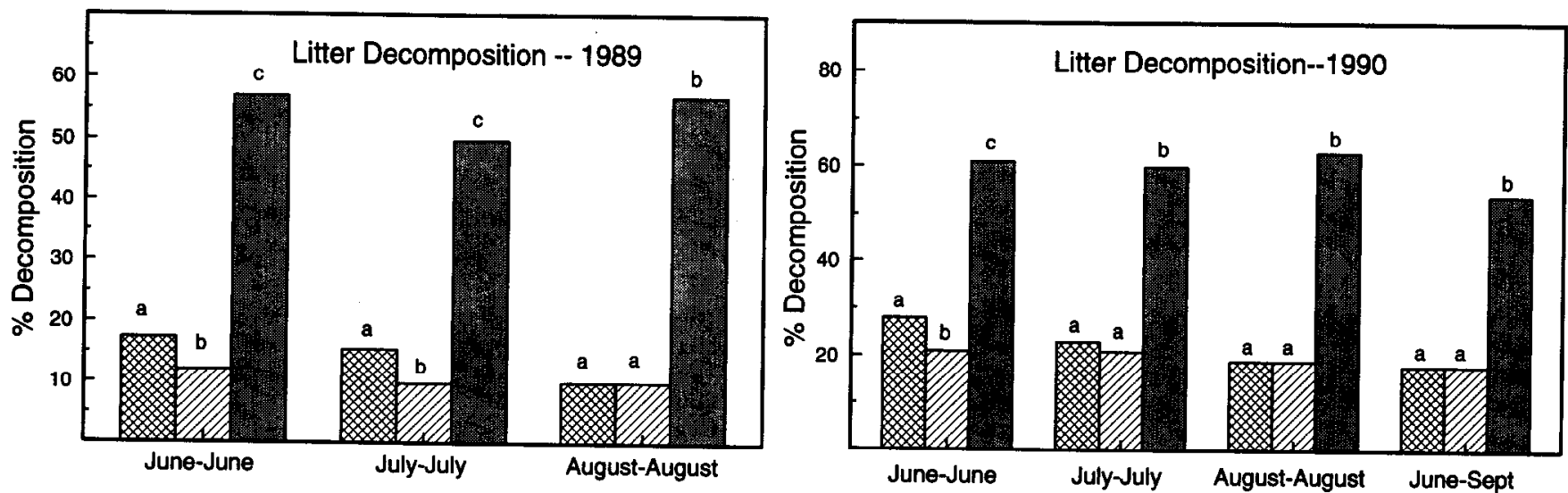

Control High Moderate
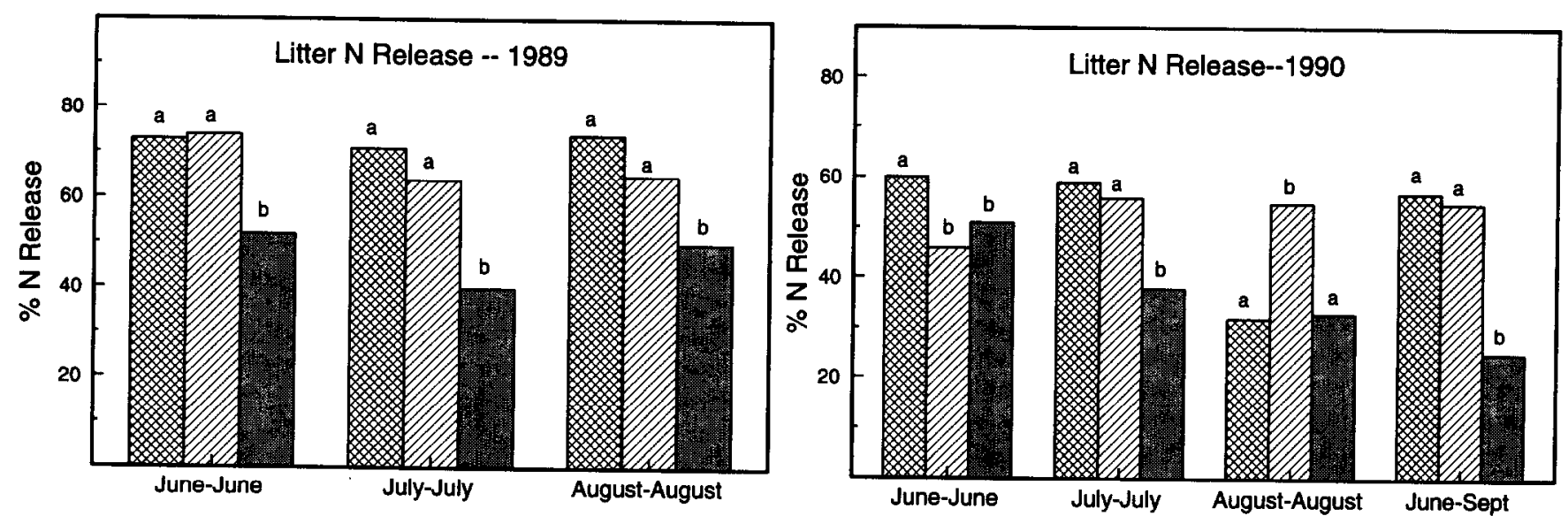

Fig. 1. Percent litter decomposition and N release for 1989 and 1990. Data under June, July, and August represent yearly rates for incubation periods that began in these months. The June-September period represent growing season rates. Control, high, and moderate represent the long term not grazed, grazed with high (77\% above-ground biomass removal), and moderate ( $44 \%$ ubove-ground biomass removal) grazing intensity treatments. Treatments within a decomposition period with different letters are statistically different $(P<0.05)$. 

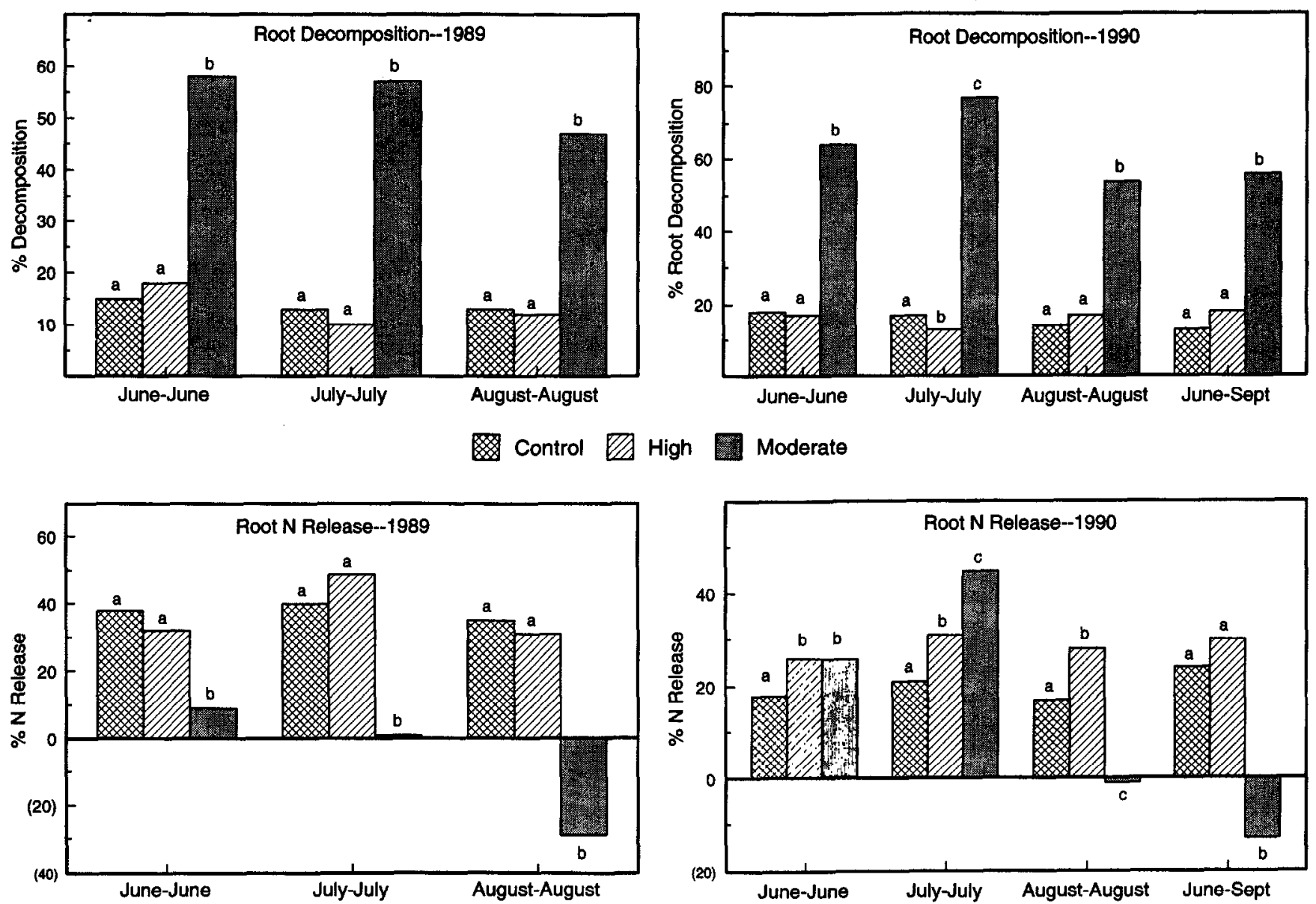

Fig. 2. Percent root decomposition and N release for 1989 and 1990. Data under June, July, and August represent yearly rates for incubation periods that began in these months. The June-September period represent growing season rates. Control, high, and moderate represent the long term not grazed, grazed with high (77\% above-ground biomass removal), and moderate ( $44 \%$ above-ground biomass removal) grazing intensity treatments. Treatments within a decomposition period with different letters are statistically different $(P<0.05)$.

b)/a*100 where $a=a$ ash-free initial dry weight or total $\mathrm{N}$ content; and $b=a s h-$ free retrieved dry weight or total $N$ content.

Soil $\mathrm{N}$ mineralization and immobilization were determined using the buried polyethylene bag technique (Westermann and Crothers 1980). Soil N sampling was conducted in June, July, and August of 1989 and 1990. At the beginning of each month, 10 samples were randomly taken from each pasture with a $5-\mathrm{cm}$ diameter soil core to a depth of $5 \mathrm{~cm}$. The samples were thoroughly mixed and sieved through a 2-mm aluminum screen to remove coarse fragments and roots. Five samples were placed in plastic bags, sealed, and immediately buried $5 \mathrm{~cm}$ below-ground. The remaining material was immediately deep frozen for initial ammonium $\mathrm{N}\left(\mathrm{NH}_{4}^{+}-\mathrm{N}\right)$ and nitrate $\mathrm{N}$ (NO3-N) determinations afterwards. Ten grams of each soil sample were extracted with $50 \mathrm{ml}$ of $2 \mathrm{~mol} . \mathrm{L}^{-1} \mathrm{KCl}$. The extract was filtered and analyzed for $\mathrm{NH}_{4}^{+}-\mathrm{N}$ using the ammonium indolephenol blue method and for $\mathrm{NO}^{-}-\mathrm{N}$ with the use of the cadmium reduction method (Page et al. 1982). Incubated samples were retrieved at the end of June, July, and August of 1989 and 1990. These samples were also analyzed for inorganic $\mathrm{N}\left(\mathrm{NH}_{4}{ }^{+}-\mathrm{N}\right.$ and $\left.\mathrm{NO}^{-}-\mathrm{N}\right)$. Soil net $\mathrm{N}$ mineralization and immobilization rates were determined as outlined in Pastor et al. (1984).

The litter and root decomposition and $\mathrm{N}$ release data were found to be heteroscedastic and non-normally distributed after tests for homogeneity of error variances, using Levene's modified method (Conover et al. 1981). The data were normalized using the arcsine transforma- tion (Sokal and Rohlf 1981). All the data were analyzed with the use of analysis of variance (SAS 1990).

\section{Results}

Litter decomposition was consistently higher $(P<0.05)$ in the moderate grazing than in the long term not grazed and heavy grazing treatments (Fig. 1). Average yearly litter decomposition rate was $55 \%$ for the moderate grazing treatment compared to $12 \%$ for the long term not grazed and heavy grazing treatments combined for the 1989-1990 incubation period, and $61 \%$ compared to $22 \%$ for the 1990-1991 incubation period. Yearly decomposition rates were higher $(P<0.05)$ in the $1990-1991$ incubation period than in the 1989 1990 incubation period for all treatments. The long term not grazed treatment had higher decomposition rates than the heavy grazing for the June 1989-1990 and 1990-1991 incubation periods as well as for the July 1989-1990 incubation period (Fig. 1). More than $80 \%$ of litter decomposition in all treatments, however, occurred during the growing season (Fig. 1). Root decomposition followed a similar pattern to the one observed for litter decomposition, with the moderate grazing treatment having consistently higher decomposition rates than the long term not grazed and heavy grazing treatments (Fig. 2) More than $60 \%$ of the root decomposition in all treatments occurred during the June to September period (Fig. 2). 

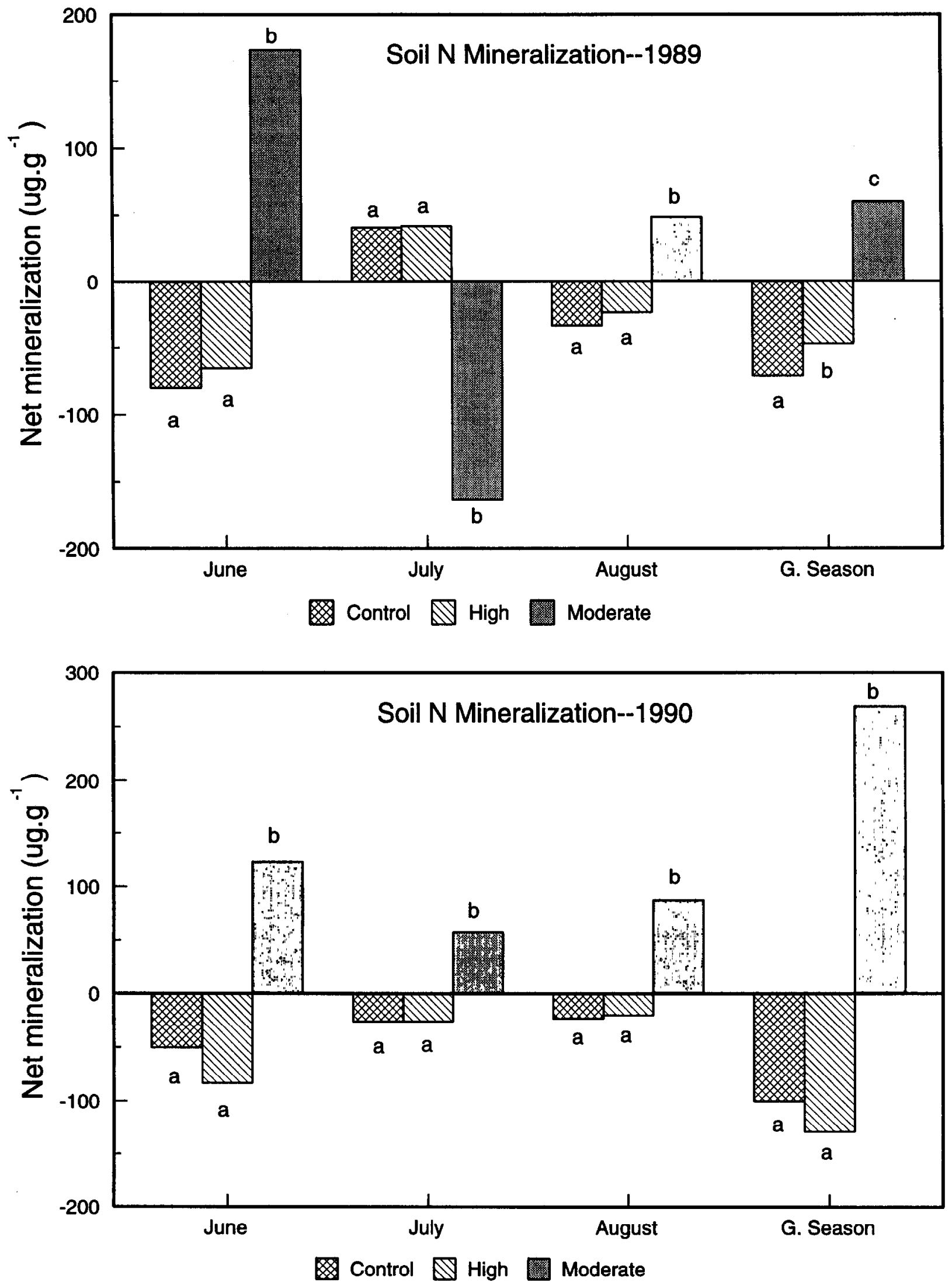

Fig. 3. Monthly and growing season net soil mineralization (positive values) or immobilization (negative values) for 1989 and 1990 ( $\mu$ g.g ${ }^{-1}$ ). Control, high, and moderate represent the long term not grazed, grazed with high ( $77 \%$ above-ground biomass removal), and moderate (44\% above-ground biomass removal) graxing intensity treatments. Treatments within an incubation period with different letters are statistically different $(P<0.05)$. 
Table 1. Average percent $\mathbf{N}$ content before and after litter and root incubation

\begin{tabular}{|c|c|c|c|c|c|}
\hline \multicolumn{3}{|c|}{ Before Incubation } & \multicolumn{3}{|c|}{ After Incubation } \\
\hline NG & HGI & MGI & NG & HGI & MGI \\
\hline * & ---.+. & 198 & tter & - & \\
\hline $1.67 \mathrm{a}$ & $1.67 \mathrm{a}$ & $\begin{array}{r}1.67 \mathrm{a} \\
198\end{array}$ & $\begin{array}{l}0.54 b \\
\text { oots }\end{array}$ & $0.60 \mathrm{~b}$ & $1.94 c$ \\
\hline $0.88 \mathrm{a}$ & $0.88 \mathrm{a}$ & $\begin{array}{r}0.88 \mathrm{a} \\
199\end{array}$ & $\begin{array}{l}0.63 b \\
\text { tter }\end{array}$ & $0.62 b$ & $1.93 \mathrm{c}$ \\
\hline $1.49 \mathrm{a}$ & $1.49 \mathrm{a}$ & $\begin{array}{r}1.49 a \\
19\end{array}$ & $\begin{array}{l}0.94 b \\
\text { Roots }\end{array}$ & $0.89 \mathrm{~b}$ & $2.25 \mathrm{c}$ \\
\hline $0.99 \mathrm{a}$ & $0.99 \mathrm{a}$ & $0.99 \mathrm{a}$ & $0.96 \mathrm{a}$ & $0.85 b$ & $2.12 \mathrm{c}$ \\
\hline
\end{tabular}

Different letters within a row denote significant difference at $P<0.05$. NG= long term not grazed treatment; $\mathrm{MGI}=$ moderate grazing ( $44 \%$ above-ground biomass removal); $\mathrm{HGI}=$ heavy grazing ( $77 \%$ above-ground biomass removal). See text for details.

The pattern of $\mathrm{N}$ release from litter and roots was contrary to the one observed for decomposition (Fig. 1 and 2). The release of $\mathrm{N}$ from the moderate grazing treatment was consistently lower $(P<0.05)$ than the one observed in the heavy grazing and long term not grazed treatments (Fig. 1). On average, yearly $\mathrm{N}$ release from litter was higher $(P<0.05)$ for the $1989-1990$ incubation period (an average $47 \%$ for the moderate grazing treatment vs $70 \%$ for the long term not grazed and heavy grazing treatments combined) than for the 1990-1991 incubation period (an average $40 \%$ for the moderate grazing treatment vs $51 \%$ for the long term not grazed and heavy grazing treatments combined) (Fig. 1). As with decomposition, most of $\mathrm{N}$ release from litter took place during the June to September incubation period (Fig. 1). Nitrogen release from roots was on average $50 \%$ lower than $\mathrm{N}$ release from litter decomposition (Fig. 1 and 2). The pattern, however, was similar: $N$ release from roots was lower $(P<0.05)$ in the moderate grazing treatment than in the long term not grazed and heavy grazing treatments (one exception was the July 1990-1991 incubation period). A major difference between $\mathrm{N}$ release from litter and root decomposition was that the moderate grazing treatment had net root $\mathbf{N}$ immobilization for the yearly August incubation periods as well as for the 1990 growing season incubation period (Fig. 2).

The moderate grazing treatment had cumulative net soil $\mathrm{N}$ mineralization for both the 1989 and 1990 growing seasons $\left(60 \mu \mathrm{g}^{-1} \mathrm{~g}^{-1}\right.$ and $\left.269 \mu \mathrm{g} . \mathrm{g}^{-1}\right)$, while the long term not grazed and heavy grazing treatments had cumulative net soil $\mathrm{N}$ immobilization for the same period (a combined average of $-59 \mu \mathrm{g} . \mathrm{g}^{-1}$ in 1989 and $-115 \mu \mathrm{g} . \mathrm{g}^{-1}$ in 1990) (Fig. 3). There were, however, differences in the monthly patterns between 1989 and 1990. In 1989, the moderate grazing treatment had net soil $\mathrm{N}$ mineralization in June and August and net soil $\mathrm{N}$ immobilization during July while the long term not grazed and heavy grazing treatments showed the opposite response (Fig. 3). In 1990 the moderate grazing treatment had consistent net soil $\mathrm{N}$ mineralization throughout the growing season while the long term not grazed and heavy grazing had consistent net soil $\mathrm{N}$ immobilization (Fig. 3).

\section{Discussion}

The empirical data on decomposition rates and soil $\mathrm{N}$ flows of this study are in partial agreement with the model predictions of Holland et al. (1992) and Seagle et al. (1992). Decomposition rates were consistently higher under moderate grazing than under no grazing or high intensity grazing. Soil $\mathbf{N}$ was consistently mineralized in the moderate grazing treatment, while it was mostly immobilized in the long term not grazed and heavy grazing treatments. The findings of this study, however, differ from Holland et al. (1992) and Seagle et al. (1992) in at least 2 areas. First, both models predict higher $\mathrm{N}$ releases from litter and root decomposition under moderate grazing (45\% grazing intensity) than under lack of grazing while our results showed the opposite. Second, both models also predict that the increases in soil net $\mathrm{N}$ mineralization under moderate grazing are the result of decreases in the root-to-shoot ratio. The moderate grazing treatment in this study, however, resulted in an increase in annual below-ground net primary productivity (Shariff 1993). In contrast, the long term not grazed and the heavy grazing treatments had consistently lower root production and lower root-to-shoot ratio (Shariff 1993). The differences observed in soil $\mathrm{N}$ mineralization and immobilization among the grazing treatments may be related to changes in the $\mathrm{N}$ concentration in litter and root substrates. As shown in Table 1, the $\mathrm{N}$ concentration in the litter and root substrates of the moderate grazing treatment increased during decomposition while in the long term not grazed and heavy grazing treatments it decreased or remained unchanged. Microbial uptake is typically greater when the $\mathrm{N}$ content of dead biomass is most limiting (Jackson et al. 1988) and thus is one of the factors that determine whether soil microbial biomass mineralizes or immobilizes $\mathrm{N}$ (Pastor et al. 1987). When usable carbon is plentiful relative to $\mathrm{N}$, microbial demand for $\mathrm{N}$ and soil $\mathrm{N}$ immobilization potentials are high. When $\mathrm{C}: \mathrm{N}$ is low, $\mathrm{N}$ immobilization potentials are low and soil net $\mathrm{N}$ mineralization may be high (Holland and Detling 1990).

Results from this study seem to indicate that the old standard grazing rule of "take half leave half" (Holechek et al. 1989) which has been recommended as a conservative management tool for the preservation of range condition, may also have a significant impact in $\mathrm{N}$ cycling, particularly in the areas of $\mathrm{N}$ conservation and the supplying of mineral $\mathrm{N}$ for plant growth. The moderate grazing treatment in this study increased the supply of mineral $\mathrm{N}$ for plants (as measured by soil net $\mathrm{N}$ mineralization) when compared with the response observed in not grazed and high intensity grazing treatments. This increase in soil net $\mathbf{N}$ mineralization is indicative of a potential mechanism for the higher levels of above-ground net primary production and $\mathrm{N}$ uptake in the moderate grazing treatment that were reported by Shariff (1993).

We also suggest that moderate grazing may lead to a greater conservation of $\mathbf{N}$ since this treatment had a higher level of $\mathrm{N}$ retention in organic matter (litter and dead roots) which should make it less susceptible to $\mathrm{N}$ losses through leaching and erosion. It should be emphasized, however, that the results observed in this study may have been significantly affected by two factors (1) the study site had not been grazed for 10 years, and (2) the study was initiated 1 year after the 1988 severe drought, and, thus, a drying and wetting cycle may have contributed to the decomposition and soil $\mathrm{N}$ mineralization rates observed in this study. We are planning to monitor these treatments for the next 10 years to determine if these response patterns are maintained.

\section{Literature cited}

Archer, S., and F.E. Smeins. 1991. Ecosystem-level processes, p. 109-139. In: R.K. Heitschmidt and J.W. Stuth (eds.). Grazing management: An ecological perspective. Timber Press, Portland, Ore.

Bauer, A., C.V. Cole, and A.L. Black. 1987. Soil property comparisons invirgin grasslands between grazed and nongrazed management systems. Soil Sci. Soc. Amer.. J. 51:176-182.

Briske, D.D., and R.K. Heitschmidt. 1991. An ecological perspective, p. 1126. In: R.K. Heitschmidt and J.W. Stuth (eds.). Grazing Management: An ecological perspective. Timber Press, Portland, Ore.

Conover, W.J., M.E. Johnson, and M.M. Johnson. 1981. A comparative study of tests for homogeneity of variances, with applications to the Outer Continental Shelf bidding data. Technometrics 23:351-361. 
Goering, H.K., and P.J. Van Soest. 1970. Forage fiber analyses. Agr. Handbook No. 379, ARS, USDA. Denver, Colo.

Holechek, J.L., R.D. Pieper and C.H. Herbel. 1989. Range Management Principles and Practices. Prentice-Hall, Inc. New Jersey, 501 p.

Holland, E.A., and J.K. Detling. 1990. Plant response to herbivory and belowground nitrogen cycling. Ecology 71:1040-1049.

Holland, E.A., W.J. Parton, J.K. Detling, and L. Coppock. 1992. Physiological responses of plant populations to herbivory and their consequences for ecosystem nutrient flow. Am. Nat. 140 (4):685-706.

Jackson, L.E., R.B. Strauss, M.K. Firestone, and J.W. Bartolome. 1988. Plant and soil nitrogen dynamics in California annual grassland. Plant Soil 110:9-17.

Jensen, R.E. 1972. Climate of North Dakota. National Weather Service, North Dakota State Univ., Fargo, N.D.

Lura, C.L., W.T. Barker, and P.E. Nyren. 1988. Range plant communities of the Central Grasslands Research Station in North Dakota. Prairie Nat. 20:177-192.

McNaughton, S.J., R.W. Ruess, and S.W. Seagle. 1988. Large mammals and process dynamics in African ecosystems. BioScience 38:794-800.

Nelson, D.W., and L.E. Sommers. 1980. Total nitrogen analysis of soil and plant tissues. J. Assoc. Off. Anal. Chemists 63:770-778.

Page, A.L., R.H. Miller, and D.R. Keeney. 1982. Methods of soil analysis:Chemical and Microbiological Properties. Amer.. Soc. Agr., Soil Sci. Soc. Amer.., Madison, Wisc..

Pastor, J., J.S. Aber, C.A. McClaugherty, and J.M. Melillo. 1984. Aboveground production and $\mathrm{N}$ and $\mathrm{P}$ cycling along a nitrogen mineralization gradient on Blackhawk Island, WISC. Ecology 65:256-268
Pastor, J., M.A. Stillwell, and D. Tilman. 1987. Nitrogen mineralization and nitrification in four Minnesota old fields. Oecologia 71:481-485.

Santos, P.F., N.Z. Elkins, Y. Steinberger, and W.G. Whitford.1984. A comparison of surface and buried Larrea tridentata leaf litter decomposition in North American hot deserts. Ecology 65:278-284.

Seagle, S.W., S.J. McNaughton, and R.W. Ruess. 1992. Simulated effects of grazing on soil nitrogen and mineralization in contrasting Serengeti grasslands. Ecology 73:1 105-1123.

Shariff, A.R. 1993. Net Primary Productivity and Nitrogen Dynamics as a Function of Grazing Intensity. Ph.D Thesis. North Dakota Stat. Univ., Fargo, N.D.

Sinclair, A.R.E. 1975. The resource limitations of trophic levels in tropical grassland ecosystems. J. Anim. Ecol. 44:497-520.

Singh, R.S., A.S. Raghubanshi, and J.S. Singh. 1991. Nitrogen mineralization in dry tropical savanna: Effects of burning and grazing. Soil Biol. Biochemistry 23:269-273.

Sokal, R.R., and F.J. Rohlf. 1981. Biometry: The principles and practices of statistics in biological research. W.H. Freeman, New York, N.Y.

SAS Institute Inc. 1990. SAS user's guide: Statistics. Version 6 edition. SAS Institute Inc., Cary, Ind.

USDA Soil Conservation Service. 1984. Missouri Coteau vegetation zoneguide to range sites. North Dakuta Tech. Guide Notice ND 35, Bismarck, N.D.

Walker, B.H., R.H. Emslie, R.N. Owen-Smith, and R.J. Scholes. 1987. To cull or not to cull: lessons from a southern African drought. J. Appl. Ecol. 24:381-401.

Westermann, D.T., and S.E. Crothers. 1980. Measuring soil nitrogen mineralization under field conditions. Agr. J. 72:1009-1012. 